\title{
African Peacekeeping and African Integration: Current Challenges
}

\author{
K. Gottschalk \\ University of the Western Cape, Bellville, the Republic of South Africa
}

\begin{abstract}
Peacekeeping and economic union are the two most important dimensions of African integration. The first section of this article aims to analyse some current challenges to African peacekeeping, peacemaking, and African integration. The continuing Libyan civil war epitomizes the diplomatic stalemates and military stalemates which form the limits of current African peacekeeping. It exposes the North African Regional Capability and North African Standby Brigade as paper structures which do not exist operationally, and so limit the capacity of the African Union's Peace and Security Council. The military intervention of states outside Africa can polarize conflicts and escalate civil wars. Africa's colonial epoch serves as a warning of the potential dangers of foreign military bases in Africa. In parts of West Africa, states sub-contract peacemaking and anti-terrorist operations to unsupervised local militias, which are lawless at best, and commit ethnic killings at worst. African integration fares better in the economic dimension. The second section analyses African integration, with its focus on the most recent step of the African Continental Free Trade Area (AfCFTA), which starts to lay the cornerstone envisaged four decades ago in the Lagos Plan of Action, and three decades ago in the Abuja Treaty for an African Economic Community. The historic track record of African continental organizations indicates that a decade will be a realistic minimum period for it to be substantially implemented. The Pan-African Payment and Settlement System will help operationalize the AfCFTA by lowering forex currency transaction charges. Severe difficulties can be predicted for future attempts to upgrade the AfCFTA into a continental customs union, and ultimately into a continental common market.

Key words: African peacekeeping, peacemaking, African integration, African Union, Peace and Security Council, African Continental Free Trade Area, Pan-African Payment and Settlement System
\end{abstract}

Acknowledgements: This article draws upon Gottschalk [2018].

For citation: Gottschalk, K. (2020). African Peacekeeping and African Integration: Current Challenges. Vestnik RUDN. International Relations, 20 (4), 678 - 686. DOI: 10.22363/2313-0660-2020-20-4-678-686

\section{Миротворческие операции в Африке и африканская интеграция: современные вызовы}

\author{
К. Готтшальк \\ Университет Западно-Капской провинции, Белвилл, ЮАР
}

\begin{abstract}
Усилия по поддержанию мира и развитию экономического взаимодействия между странами - два наиболее важных аспекта африканской интеграции. В первом разделе автор анализирует некоторые текущие вызовы африканскому миротворчеству, миростроительству и африканской интеграции. Продолжающаяся гражданская война в Ливии олицетворяет дипломатические и военные тупики, которые ограничивают нынешнюю миротворческую деятельность в Африке. Она демонстрирует, что Североафриканские региональные силы и Североафриканская резервная бригада существуют только на бумаге, а в реальности действуют неэффективно, тем самым
\end{abstract}

(C) Gottschalk K., 2020

This work is licensed under a Creative Commons Attribution 4.0 International License.

https://creativecommons.org/licenses/by/4.0/ 
ограничивая возможности Совета мира и безопасности Африканского союза. Военное вмешательство внерегиональных акторов может поляризовать конфликты и привести к эскалации гражданских войн. Колониальная эпоха в истории Африки служит предупреждением о потенциальной опасности иностранных военных баз на континенте. В некоторых частях Западной Африки государства поручают миротворческие и антитеррористические операции неконтролируемым местным ополченцам, которые в лучшем случае действуют вне рамок закона, а в худшем - совершают убийства на этнической почве. Во втором разделе анализируется африканская интеграция с акцентом на последнем этапе создания Африканской континентальной зоны свободной торговли (АфКЗСТ), которая начинает закладывать краеугольный камень, предусмотренный четыре десятилетия назад в Лагосском плане действий и три десятилетия назад в Договоре об Африканском экономическом сообществе, подписанном в г. Абуджа. Исторический послужной список африканских континентальных организаций указывает на то, что десятилетие будет реалистичным минимальным периодом для его существенной реализации. Панафриканская система платежей и расчетов поможет ввести в действие АфКЗСТ за счет снижения комиссии за валютные транзакции. Можно предвидеть серьезные трудности в отношении будущих попыток превратить АфКЗСТ в континентальный таможенный союз и в конечном итоге в общий континентальный рынок.

Ключевые слова: африканское миротворчество, миростроительство, африканская интеграция, Африканский союз, Совет мира и безопасности, Африканская континентальная зона свободной торговли, Панафриканская система платежей и расчетов

Благодарности: Эта статья основана на ранее опубликованной работе автора [Gottschalk 2018].

Для цитирования: Gottschalk K. African Peacekeeping and African Integration: Current Challenges // Becтник Российского университета дружбы народов. Серия: Международные отношения. 2020. Т. 20. № 4. C. 678 -686. DOI: 10.22363/2313-0660-2020-20-4-678-686

\section{Introduction}

This article aims to analyse some current challenges to African peacekeeping and African integration. It is based on desktop research and is qualitative in method.

From the start of the Libyan civil war in the Arab Spring of 2011, divisions between African governments, and between African and Arab governments, persisted. NATO states were able to play off the Arab League, wanting strong action against Gaddafi, against the African Union (AU), which sought to mediate between the Libyan ruler and the rebels in Benghazi. In addition, the South African Government voted for the UN Security Council resolution calling for protection of Libyans against Gaddafi's repressions, which rapidly saw mission creep from NATO states [Murithi 2012: 97], culminating in the overthrow of Gaddafi.

\section{African Peacemaking}

While the African Union legally operates by a majority vote, not consensus, in its summit assemblies, it in practice avoids taking up issues where major African states have already taken opposite stands in public. One example is that when, after an international arbitration award in
$2002^{1}$, Ethiopia did not return the small rural town of Badme to Eritrea for two decades, not once did the African Union censure it. One obvious reason is that Ethiopia hosts the headquarters of both the African Union, its Peace and Security Council, and more than one other affiliate.

Another example is the dispute between Egypt and Ethiopia over the rate of filling of the newest dam on the Blue Nile river, the Grand Ethiopian Renaissance Dam. The U.S. Government became involved in mediation negotiations well before the African Union. The relevant Regional Economic Community, the Common Market of Eastern and Southern Africa (COMESA), which should have taken the lead under the principle of subsidiarity, has not initiated any mediation.

In recent years extra-African governments have backed opposing sides in Libya. The UN-recognized Tripoli-based Government of National Accord has attracted military and diplomatic support from Turkey and Qatar. The

${ }^{1}$ Reports of International Arbitral Awards. Decision Regarding Delimitation of the Border between Eritrea and Ethiopia, 13 April 2002 // United Nations. URL: https://legal.un.org/riaa/cases/vol_XXV/83-195.pdf (accessed: 04.05.2020). 
Tobruk-based Libyan National Army gets diplomatic and military support from the United Arab Emirates ${ }^{2}$, Jordan and Egypt. Usually, African states regard regionalism as «a useful defence against external domination and a means of finding a collective voice» [Levine, Nagar 2016: 28], but in this case divergent views meant that this was not possible.

The African Union has attempted to negotiate $^{3}$. This is constrained by the fact that individual African governments have sympathies to different sides. Other problems include that, first, the AU's African Standby Force has not been operationalized, a decade after its planned launch in 2010. Second, the African Union operates on a basis of subsidiarity. The relevant regional economic community, the Arab Maghreb Union (AMU), has failed to hold a high-level meeting since 2008, largely due to Algerian and Moroccan conflict over the issue of the Sahrawi Arab Democratic Republic, which Morocco has annexed. To circumnavigate this, the African Union sought to establish the North African Regional Capability (NARC) in 2007. This is responsible for deploying a North African Standby Brigade (NASBRIG) and runs a liaison office at the AU headquarters ${ }^{4}$.

The scale of the Libyan civil war would in fact require a peacemaking force totalling divisions in strength, like AMISOM, not one brigade. But even that brigade has never deployed, due to different sympathies by North African governments. This exposes the North African Regional Capability and North African Standby Brigade as paper structures which do not exist operationally, and so limit the capacity

${ }^{2}$ AU Calls for Consolidated Efforts to Face Challenges in Libya's Crisis // The Libya Observer. September 29, 2019. URL: https://www.libyaobserver.ly/inbrief/ au-calls-consolidated-efforts-face-challenges-libyas-crisis (accessed: 29.03.2020).

${ }^{3}$ French Sources: UAE Sent 3,000 Tons of Military Support to Haftar // The Libya Observer. February 01, 2020. URL: https://www.libyaobserver.ly/news/ french-sources-uae-sent-3000-tons-military-support-haftar (accessed: 02.02.2020).

4 The Regional Economic Communities (RECs) // African Union. URL: https://au.int/en/organs/recs (accessed: 02.02. 2020). of the African Union's Peace and Security Council.

Third, there is policy incoherence within an individual state such as South Africa. President Cyril Ramaphosa, in his capacity as current AU chair, asked Turkey to not militarily intervene in Libya, while one South African state-owned company, DENEL, simultaneously sells munitions to Turkey ${ }^{5}$ which already militarily intervenes on the side of the GNA, sending it munitions.

Few of the African governments say anything in public about the Libyan war, but the consequences of these factors ensure that the AU has been marginalized in attempts at peacekeeping and peacemaking in Libya.

Similar problems also impinge on peace keeping and peacemaking in west Africa states. Insurgents are currently active in some states which are Economic Community of West Africa (ECOWAS) members, such as Burkina Faso, Mali, Niger, and Nigeria; and other states which are Economic Community of Central African States (ECCAS) members, such as the Cameroon and Chad; while Mauretania is a member of the dormant AMU. The response of states to this has been to set up ad hoc military missions, such as the G5 Sahel, founded in 2014, and the MultiNational Joint Task (MNJTF) ${ }^{6}$, founded in 1994, which overlap with memberships of at least three RECs: ECOWAS, ECCAS, and the dormant AMU. Unintended consequences include that the formal institutional relationship between the AU and an REC does not have official space for the MNJTF, G5 Sahel, and similar ad hoc entities. It means that individual states, rather than ECOWAS or the AU as such, drive operations.

Peacemaking has led to the establishment of some of the foreign military bases in Africa. In April 2016, the AU's Peace \& Security Council called on member states to be "circumspect" when "entering into agreements" that would lead

${ }^{5}$ Ebrahim S. NCACC Must Block Munitions Sold to Countries at War // The Independent Online. May 17, 2020. URL: https://www.iol.co.za/news/opinion/ncaccmust-block-munitions-sold-to-countries-at-war-48043811 (accessed: 09.05.2020).

6 The Multinational Joint Task Force (MNJTF) // MNJTF. URL: https://www.mnjtf-fmm.org (accessed: 02.02.2020). 
to the establishment of foreign military bases in their countries ${ }^{7}$. There are at least 27 known U.S. military outposts across Africa. At least eleven states from outside Africa have a military presence. Numerically, the largest are 7550 French military personnel, and 6000 US military personnel at 27 outposts $^{8}$. One foreign country's presence was limited to only mercenaries, but what are currently termed defence contractors or consultants obviously require passports and official toleration, as in line with the foreign policy of their home state, for combat work abroad. In the colonial epoch, foreign military bases underpinned imperial rule in Africa. Even in the post-colonial half-century, scores of French military bases and interventions saw the overthrow of some Francophone rulers. Today, foreign military bases are in Africa as negotiated, to pay rental with the host governments, but the potential to undermine national and continental sovereignty always remains.

Another constraint on the capacity of subregional communities is "their unwillingness to surrender sovereignty to communal mechanisms, and the absence of common values amongst them" [Nathan 2013b: 187]. Nathan's analysis refers to the Southern African Development Community (SADC), but it indeed also applies to most of its peers in other parts of the continent.

Another dimension of peacemaking cannot go without consideration. Lawlessness and human rights abuses in anti-terrorist operations are daunting problems in many Sahel states. ECOMOG troops "became heavily involved in warlord politics and plunder", nicknamed "Every Commodity and Movable Object Gone" [Taylor 2014: 234]. Power-sharing peace agreements to end civil wars come at the heavy cost that they "sanctioned impunity through amnesty, whether de jure or de facto" [Levitt 2012: 123].

7 Atta-Asamoah A. Proceed with Caution: Africa's Growing Foreign Military Presence // Institute for Security Studies (ISS). August 27, 2019. URL: https://issafrica.org/ iss-today/proceed-with-caution-africas-growing-foreignmilitary-presence (accessed: 29.08.2019).

8 Turse N. Exclusive: The US Military's Plans to Cement Its Network of African Bases // Mail \& Guardian. May 1, 2020. URL: https://mg.co.za/article/2020-05-01exclusive-the-us-militarys-plans-to-cement-its-network-ofafrican-bases/ (accessed: 10.05.2020).
Tacit outsourcing of the fight against jihadists to vigilante groups with scores to settle unleashes ethnic violence across the Sahel. In Burkina Faso, an ethnic Mossi militia group killed dozens of Fulani in revenge for the killing of a village chief by jihadists. 157 Fulani villagers, including women and children, were killed in Mali by Dogon armed men ${ }^{9}$. Scholars analysing terrorism need to also be aware of the "danger of valorization of predatory state elites" [Devon 2013: 16].

Kenyan military and police summarily executed al-Shabaab suspects ${ }^{10}$. In Nigeria, the lawless terror of the Nigerian police, army, and militias, including extra-judicial killings, alienated many citizens whose cooperation against Boko Haram ${ }^{11}$ is essential to its defeat ${ }^{12}$. One Nigerian army massacre alone killed 347 Shia Muslim followers of Zakzaky, whose corpses were dumped in a mass grave ${ }^{13}$. The same applies to the Malian army. Malian army abuses during counter-terrorism operations include arbitrary arrests, torture, and scores of extra-judicial executions ${ }^{14}$. One UN research monograph reports that the trigger event which

\footnotetext{
${ }^{9}$ Death Toll from Attack on Mali Herders Rises to $157 / /$ Reuters. March 27, 2019. URL: https://www.reuters.com/ article/mali-security-idAFL8N21D74X (accessed: 29.08.2019).

${ }^{10}$ Kenyans in Fear of Police 'Death Squads' // BBC. July 7, 2016. URL: https://www.bbc.com/news/worldafrica-36733808 (accessed: 29.08.2019).

11 "Boko Haram" is in fact one of its slogans; its actual name is Jama'atu Ahlis Sunna Lidda'awati wal-Jihad.

12 Taub B. Lake Chad: The World's Most Complex Humanitarian Disaster // The New Yorker. November 27, 2017. URL: https://www.newyorker.com/magazine/2017/ 12/04/lake-chad-the-worlds-most-complex-humanitariandisaster (accessed: 01.05.2020); Matfess H. Nigeria Wakes Up to Its Vigilante Problem // The New Humanitarian. May 9, 2017. URL: https://www.thenewhumanitarian.org/ analysis/2017/05/09/nigeria-wakes-its-growing-vigilanteproblem (accessed: 29.08.2019). See also: [Solomon 2015: 225].

13 Nigeria: 'Army Killed 347 Shia Followers of elZakzaky' // Aljazeera. August 2, 2016. URL: https://www.aljazeera.com/news/2016/08/nigeria-armykilled-347-shia-followers-zakzaky-160802071409995.html (accessed: 10.05.2020).

${ }^{14}$ Dufka. C. Il n'y a pas d'issue militaire au bourbier malien // Jeune Afrique. 19.05.2017. URL: https:/www.jeuneafrique.com/440007/politique/ny-adissue-militaire-bourbier-malien/ (accessed: 20.04.2020).
} 
caused $71 \%$ of insurgents to join a violent extremist organization in Africa was state security forces' arrest or killing of a friend or family member [Ojielo et al. 2017].

Ultimately, most civil wars require a negotiated political solution for permanent peace, not just military re-conquest. In previous years, the AU used the slogan "the guns must fall silent by 2020". In 2020 itself, they seem to have quietly shelved the words "by 2020" in that slogan.

\section{African Integration}

Since the Organisation of African Unity (OAU) was founded in 1963 with three organs, the African Union has blossomed with a proliferation of institution-building, until it now comprises over sixty organs, specialized technical agencies, and affiliate entities [Gottschalk 2012: 27].

The African Continental Free Trade Area (AfCFTA) starts to lay the cornerstone for defragmenting Africa that was envisaged four decades ago in the OAU's Lagos Plan of Action, and three decades ago in the Abuja Treaty for an African Economic Community. The historic track record of African continental organizations indicates that a decade will be a realistic minimum period for it to be substantially implemented. Severe difficulties can be predicted for the scheduled future attempts to upgrade the AfCFTA into a continental customs union, and ultimately into a continental common market. Africa will not follow in detail Europe's path [Fioramonti, Mattheis 2016].

Africa's economic potential may be judged by the facts that it has 1.3 billion people, and a combined GDP of USD 3 trillion. The Treaty for an African Economic Community was signed in Abuja in 1991 and came into force in 1994. Its Article 6 and its schedule calls for a continental free trade area by 2017; a continental customs union by 2019; a continental common market by 2023, and a continental single currency by 2034 . The African Continental Free Trade Area came into force legally in 2019.

It will take at least a decade to be substantially implemented. As this article goes to press, the AfCFTA still has to negotiate between member states the rules of origin (RoO), a protocol on Non-Tariff Barriers (NTBs), and a Dispute Resolution Mechanism. Episodic setbacks will be inevitable: for example, three months after signing the AfCFTA, Nigeria's Government imposed a total ban on all imports from or through its neighbours Benin, Niger, and Cameroon.

To upgrade the AfCFTA into a continental customs union, one of the biggest obstacles to negotiate will be that already Morocco (in 2000), Egypt (in 2004), and Tunisia (in 2008) all signed free trade association agreements with the EU. Egypt has since 1997 also been a member of the Arab League Free Trade Union. One hundred Morocco aerospace firms participate in international supply chains. Unless a future African customs union sets at $0 \%$ import duties from the EU, its mere establishment would require those three states to withdraw from, or at least to substantially re-negotiate their FTAs with the EU. Mangeni and Juma alert us that: "Free Trade Agreements with some third-party countries are resulting in adverse implications for the... integration programme. This trend is observed in many other AU states and is likely to come back to haunt the continent's integration process" [Mangeni, Juma 2018: 104].

The EU tried strenuously to demand in Economic Partnership Agreement negotiations that ECOWAS abandon its revenue source of levying a $0.5 \%$ import duty on all nonECOWAS imports, and only backed off when all ECOWAS members stood up to it [Momodu 2018: 101-102]. The East African Community (EAC) deploys a similar levy.

One scholar reminds us that non-tariff barriers are far more pernicious impediments to intra-Africa trade than tariffs ${ }^{15}$. The potential benefits of merging sub-regional free trade areas, and upgrading transport infrastructure, are in too many cases negated by corruption at borders and along the highways. The problem of extortion by police or militia serial roadblocks, each acting

15 Hartzenberg T. Some Reflections on Africa Day 2020, COVID-19 and the AfCFTA // Trade Law Centre. May 25, 2020. URL: https://www.tralac.org/blog/article/ 14623-some-reflections-on-africa-day-2020-covid-19-andthe-afcfta.html (accessed: 26.04.2020). 
like feudal toll barons on the Rhine and Danube rivers, occurs in country after country.

Roadblocks by rival Kenyan police forces on the Lake Victoria to Mombasa road extort the equivalent of USD 100 from lorry drivers ${ }^{16}$. Between Côte d'Ivoire and Burkina Faso, the Abidjan-Yamoussoukro road has five roadblocks demanding bribes ${ }^{17}$. One freight company in Boksburg, South Africa, has to issue each lorry driver with the equivalent of USD 200 in US banknotes to pass roadblocks in the DRC ${ }^{18}$. Two provinces alone, North and South Kivu, in the DRC have 798 roadblocks demanding tolls [Schouten, Murari, Kubya 2017]. The Zimbabwe police also harass drivers for bribes ${ }^{19}$ and officials demand at least USD $6^{20}$.

The cumulative consequences of such corruption, as with medieval tolls, are to limit long-distance trade to only high value items. All told, corruption costs Africa an estimated $25 \%$ of its combined national income per year [Landsberg 2013: 126].

Another problem is policy incoherency [Nathan 2013b]. For example, South Africa's Department of International Relations (DIRCO) and the Department of Trade and Industry (DTI) spent a decade negotiating first a Tripartite Free Trade Area, followed by the AfCFTA, both of which, amongst other achievements, would enable trade with no customs tariffs all the way from Cape Town to Cairo, traversing eight countries. But, simultaneously, the South African National Roads Agency Limited (SANRAL), imposed two tolls (du Toit's Kloof tunnel, and through Gauteng Province) on lorries transporting cargo between Cape Town and the

${ }^{16}$ African Independent. January 12, 2016.

17 The 1.2 billion Opportunity. Business in Africa // The Economist. April 16, 2016. URL: http://www.economist.com/sites/default/files/20160416_af rica.pdf (accessed: 26.05.2020).

18 Sunday Times. October 3, 2010.

${ }^{19}$ Cross E. Reflections on Corruption in Zimbabwe // Politicsweb. November 27, 2016. URL: http://www.politicsweb.co.za/opinion/reflections-oncorruption-in-zimbabwe (accessed: 06.05.2020).

20 Manayiti O. Zimbabwe: Face to Face With Beitbridge's Daring Smuggling Syndicates // Zimbabwe Standard. December 04, 2016. URL: http://allafrica.com/ stories/201612040244.html (accessed: 06.05.2020).
Zimbabwean border. If the remaining seven states between South Africa and Cairo were each to follow suit, a freight company would have to pay sixteen road tolls along the Cape to Cairo route, rendering overland trade unprofitable.

A cognate problem goes beyond policy incoherency. It can best be highlighted by starting with law scholars, who sometimes take treaty texts at face value. Alvarez notes of the $\mathrm{AU}$ and some RECs: "The treaty provisions establishing these African institutions anticipate international organisations charged with discharging the kinds of plenary executive, legislative, and even judicial powers once associated exclusively with national governments" [Alvarez 2005: 116].

Levitt judges that the AU's Charter on Democracy, Elections and Governance "is indisputably the most progressive treaty on democracy and governance in the world" [Levitt 2012: 225]. Gathii singles out the judiciaries in the ECOWAS Community Court of Justice and in the SADC Tribunal for being "exemplary in making bold decisions, which were not well received by member states" [Gathii 2011: 297] but also warns readers that "it is a truism that the legal obligations assumed under these treaties are not understood by the leaders as containing punitive sanctions for non-compliance" [Gathii 2011: 27].

Only one scholar has pointed out the bombshell revelation that no other researcher mentions. Referring to the presidential summits of AU countries, he emphasises: "The only contact many of the Assembly members had with these documents were during summits at which they were asked to approve them. A majority of them did even see the colour of the cover page or had the chance to read even the executive summary of those plans before rubber-stamping them" [Tieku 2017: 8].

The inevitable consequence is that when such treaties result in adverse consequences for them, Mugabe, for example, denounced the SADC Tribunal judgments as "nonsense... of no consequence", and led the SADC in dissolving the SADC Tribunal, and narrowing the jurisdiction of the protocol [Nathan 2013a: 876]. The head of the tribunal surmised that the 
SADC-T protocol was just a gambit to get funds from the EU and others [Nathan 2013a: 883]. Likewise, two scholars concluded that the Economic Community of Central African States (ECCAS) offer "savvy regimes with another avenue through which they can access donor funding" [Palmateer, Clark 2018: 127-128]. Another writer concludes that ECOWAS, ECCAS, and COMESA "failed to achieve their integration goals" [Adebajo 2016: 63]. Vines concludes on a more optimistic note that multiple REC memberships provide more opportunities for conference diplomacy between presidents [Vines 2013: 102].

Another failure with escalating consequences is the failure to provide compensation mechanisms for least developed economies entering free trade areas, customs unions, or a common market: "Given the absence of distributional mechanisms, laissez-faire market integration increased internal disequilibria" [Zajontz, Leysens 2015: 306]. On its own, free trade can create loser regions and economic sectors, as well as winners: "For many years, certain countries like Nigeria, Kenya, Egypt and South Africa have been deemed by their partners to be benefiting more in their respective trading blocs... The lifeline of any integration undertaking is hinged on greater equity in the distribution of benefits amongst all the member countries" [Irungu 2014: 243].

The ECCAS Protocol on the Fund for Compensation for Loss of Revenue has not yet been implemented. The ECOWAS treaty of 1975 Article 50 (Article 21 in 1993 revised treaty) specified an ECOWAS Fund for Cooperation, Compensation, \& Development — which no member state would fund. Instead, as next-best, the ECOWAS Bank for Investment \& Development (EBID) was set up: but a bank cannot make substantive grants, only loans.

The African Economic Community Treaty of 1991, article 80, also requires founding and capitalizing a Solidarity, Development, and Compensation Fund. Three decades later, there is no trace of it. The COMESA Adjustment Facility is the only such fund that is operational - and is entirely dependent on western donors.

Even in the third largest economy on the continent, South Africa, the SA Paint
Manufacturing Association (SAPMA) has complained that the T-FTA agreement leaves them disadvantaged by the future imports of Egyptian paint with export subsidies ${ }^{21}$.

As the FTAs and Customs Unions which exist on paper become actually implemented, the need for such compensatory mechanisms for the least developed countries becomes more urgent. Currently, only the Southern African Customs Union (SACU) has South Africa pay de facto annual compensation to Botswana, Lesotho, Namibia, and eSwatini for lowering customs duties upon which they depend for government revenue. In the continental context, the oilwindfall states could capitalize such a fund.

Other states such as South Africa could offer asymmetric and variable geometry terms: soft borders for certain migrant workers; lower bank forex fees for remittances; and grants for trans-border transport and energy infrastructure, are amongst feasible modes of compensation. In the specific case of South Africa, compensation could also take the mode of providing pensions and medical aid, especially for respiratory diseases and STDs, to former migrant mine workers who after retirement, retrenchment, or medical boarding out, have returned to their family homes in Lesotho or southern Mozambique.

The signing of the African Continental Free Trade Area (AfCFTA) protocol makes the case for compensatory mechanisms to regions and states who lose out, more important. The AfCFTA is envisioned in both the African Economic Community treaty of 1991 , and in the AU Minimum Integration Programme, as merely one stage towards a continental customs union, followed by the next stage of a continental common market. Delay in addressing this point risks a rising backlash against Pan-African integration, as is already occurring amongst some voters of countries within the European Union and led to Brexit.

${ }^{21}$ Cokayne R. Exclusive: Thousands of Paint Industry Jobs at Risk // Business Report. September 15, 2017. URL: https://www.iol.co.za/business-report/companies/ exclusive-thousands-of-paint-industry-jobs-at-risk11222099 (accessed: 06.05.2020). 
The AfCFTA is still divided up into over a score of different currencies, fluctuating daily in relative value, and some of which are not freely convertible. Even in an era of bank cards, ATMs, and mobile phone money transfers, this exacts transaction costs, and does not provide stability for trade. Eight west Africa countries share the Eco, with which currency five Anglophone states have struggled unsuccessfully for over two decades to merge their own currencies. In east Africa, six states are still battling after more than a decade to merge their currencies.

One problem of what we could term practical Pan-Africanism is to lower the extortionate bank charges on exchanging foreign currencies in Southern Africa, which hurt the African diasporas of migrant workers when they remit what they can afford to their families back at home across international borders. Creating a continental currency, the Afro, to judge by the EU's travails with the Euro, could take another half a century. An immediate mitigation comes through entrepreneurs in Kenya pioneering $\mathrm{M}$ Pesa, which can be sent by mobile phone across some borders, with significantly lower fees. Similar money transfer firms have sprung up in South Africa to compete against the bank charges for migrant workers remitting money across borders to their families.

The Pan-African Payment and Settlement System, launched in 2019 by the African Export and Import Bank (Afreximbank), avoids use of the dollar and other third party currency costs in transactions between African countries, and will so save an estimated USD 5 billion per year ${ }^{22}$. This is one more incremental step towards PanAfrican ways of doing trade, prior to the merging of currencies. This is one bright note, unlike the AU's "Sixth Region" for the African diaspora living abroad from the continent, which has after 2012 fallen dormant [Maloka 2019: 227, 233].

\section{Conclusions}

The classical definition of peacekeeping to keep the peace after a ceasefire between two rival armies - has long been obsolete in Africa. The modern situation is peacemaking: a military intervention against one, or all, combatant sides in ongoing civil wars. This requires immeasurably larger troop commitments, and always the interveners are in it for the long haul, over a decade on average. The AU, the AMU, and the COMESA have not yet been effective in ending the Libyan civil war.

In the economic dimension of African integration, it is appropriate to invoke Braudel's longue durée [Edozie, Gottschalk 2014: 84] as institution-building of a continental free trade area, and sub-regional customs unions and common markets, each take a generation or two. A continental common market, and a continental single currency, will probably take half a century, evoking the AU's 2063 vision.

22 Wass S. Africa's Continent-wide Payment and Settlement System Launched // Global Trade Review. July 9, 2019. URL: https://www.gtreview.com/news/africa/ africas-continent-wide-payment-and-settlement-systemlaunched/ (accessed: 23.05.2020).

Received / Поступила в редакцию: 12.08.2020

Accepted / Принята к публикации: 21.09.2020

\section{References / Библиографический список}

Adebajo, A. (2016). A Tale of Three Cassandras: Jean Monnet, Raul Prebisch, Adebayo Adedeji. In: Levine, D.H. \& Nagar, D. (Eds.). Region-Building in Africa. Political and Economic Challenges. New York: Palgrave Macmillan. P. 53-67.

Alvarez, J. (2005). International Organisations as Law-Makers. Oxford: Oxford University Press.

Devon, C. (2013). The Contested Politics of Peacebuilding in Africa. In: Curtis, D. \& Dzinesa, G.A. (Eds.). Peacebuilding, Power and Politics in Africa. Athens, Ohio: Ohio University Press. P. $1-31$.

Edozie, R. \& Gottschalk, K. (2014). The African Union's Africa: New Pan-African Initiatives in Global Governance. East Lansing: Michigan State University Press.

Fioramonti, L. \& Mattheis, F. (2016). Is Africa Really Following Europe? An Integrated Framework for Complementary Regionalism. Journal of Common Market Studies, 54 (3), 1-17. URL: https://papers.ssrn.com/sol3/papers.cfm?abstract_id=2764560 (accessed: 10.06.2020). 
Gathii, J. (2011). African Regional Trade Agreements as Legal Regimes. Cambridge: Cambridge University Press.

Gottschalk, K. (2012). The African Union and its Sub-Regional Structures. Journal of African Union Studies, 1 (1), 9-39.

Gottschalk, K. (2018). Persistent Problems in African Integration and Peace-keeping. Journal of African Union Studies, 7 (3), 67-89. DOI: 10.31920/2050-4306/2018/V7n3a4

Irungu, E. (2014). The African Union and African Regional Integration. R/evolutions Global Trends \& Regional Issues, 2 (1), 238-249.

Landsberg, C. (2013). Peace-building as Governance. The Case of the Pan-African Ministers Conference for Public and Civil Service. In: Curtis, D. \& Dzinesa, G.A. (Eds.). Peacebuilding, Power and Politics in Africa. Athens, Ohio: Ohio University Press. P. 121-139.

Levine, D. \& Nagar, D. (Eds.). (2016). Region-Building in Africa. Political and Economic Challenges. New York: Palgrave Macmillan.

Levitt, J. (2012). Illegal Peace in Africa. An Inquiry into the Legality of Power-Sharing with Warlords, Rebels, and Juntas. Cambridge: Cambridge University Press.

Maloka, E. (2019). When Foreign becomes Domestic. The Interplay of National Interests, Pan-Africanism, and Internationalism in South Africa's Foreign Policy. Johannesburg: Ssali Publishing House.

Mangeni, F. \& Juma, C. (2018). Emergent Africa. Evolution of Regional Economic Integration. Terra Alta, WV: Headline Books.

Momodu, R. (2018). Nationalism Underpinned by Pan-Regionalism: African Foreign Policies in ECOWAS in an Era of Anti-Globalization. In: Warner, J. \& Shaw, T. (Eds.). African Foreign Policies in International Institutions. New York: Palgrave Macmillan. P. 95-112.

Murithi, T. (2012). The African Union and the Libya Crisis: Situating the Responsibility to Protect in Africa. Journal of African Union Studies, 1 (1), 83-88.

Nathan, L. (2013a). The Disbanding of the SADC Tribunal: A Cautionary Tale. Human Rights Quarterly, 35 (4), 870-892. DOI: $10.1353 /$ hrq.2013.0059

Nathan, L. (2013b). Synopsis of Community of Insecurity: SADC's Struggle for Peace and Security in Southern Africa. African Security Review, 22 (3), 181-189. DOI: 10.1080/10246029.2013.822667

Ojielo, O. et al. (2017). Journey to Extremism in Africa: Drivers, Incentives and the Tipping Point for Recruitment. United Nations Development Programme Report, $1-113$.

Palmateer, G. \& Clark, J. (2018). The Uses (and Abuses) of the Economic Community of Central African States. The Hidden Functions of Regional Economic Community Membership for African Regimes. In: Warner, J. \& Shaw, T. (Eds.). African Foreign Policies in International Institutions. New York: Palgrave Macmillan. P. 127-148.

Schouten, P., Murari, J. \& Kubya, S. (2017). "Everything That Moves Will Be Taxed": The Political Economy of Roadblocks in North and South Kivu. IPIS/DIIS Report, 1-66.

Solomon, H. (2015). Critical Terrorism Studies and its Implications for Africa. Politikon. South African Journal of Political Studies, 42 (2), 219-234. DOI: 10.1080/02589346.2015.1041671

Taylor, R. (2014). Regional Governance in Africa. R/evolutions Global Trends \& Regional Issues, 2 (1), 220-237.

Tieku, T. (2017). Governing Africa: 3D Analysis of the African Union's Performance. Lanham: Rowman and Littlefield.

Vines, A. (2013). A Decade of African Peace and Security Architecture. International Affairs, 89 (1), 89-109. DOI: $10.1111 / 1468-2346.12006$

Zajontz, T. \& Leysens, A. (2015). Regionalism Revisited: A Critical-reflectivist Framework for Engaging the Changing Nature of Developing Regionalisms in Africa. Politikon. South African Journal of Political Studies, 42 (3), 299-323. DOI: 10.1080/02589346.2015.1104465

About the author: Gottschalk Keith - Political Scientist, Member (retired), the Political Studies Department, University of the Western Cape, Bellville, Republic of South Africa (e-mail: kgottschalk@uwc.ac.za).

Сведения об авторе: Готтшальк Кит - политолог, сотрудник (на пенсии) факультета политических исследований Университета Западно-Капской провинции, Белвилл, Южно-Африканская Республика (е-mail: kgottschalk@uwc.ac.za). 